\title{
Editorial
}

\section{Sustainable Drainage Systems}

\author{
Miklas Scholz \\ Civil Engineering Research Group, School of Computing, Science and Engineering, The University of \\ Salford, Newton Building, Salford, Greater Manchester M5 4WT, UK; \\ E-Mail: m.scholz@salford.ac.uk
}

Received: 8 May 2015 / Accepted: 13 May 2015 / Published: 15 May 2015

Urban water management has somewhat changed since the publication of The Sustainable Drainage System (SuDS) Manual in 2007 [1], transforming from building traditional sewers to implementing SuDS, which are part of the best management practice techniques used in the USA and seen as contributing to water-sensitive urban design in Australia. Most SuDS, such as infiltration trenches, swales, green roofs, ponds, and wetlands, address water quality and quantity challenges, and enhance the local biodiversity while also being acceptable aesthetically to the public. Barriers to the implementation of SuDS include adoption problems, flood and diffuse pollution control challenges, negative public perception, and a lack of decision support tools addressing, particularly, the retrofitting of these systems while enhancing ecosystem services.

This Special Issue on SuDS disseminates recent findings on current challenges faced by practicing sustainable drainage engineers and scientists. Twelve papers were selected in a rigorous peer review procedure with the aim of rapid and wide dissemination of research results and critical reviews, as well as developments and applications of relevance to both academics and practitioners. Original research papers and reviews addressing the following and related areas were initially invited: infiltration techniques, ponds and wetland systems, adoption of sustainable drainage systems, climate change adaptation measures, public perception of sustainable drainage, integration of sustainable drainage into water-sensitive urban design, and SuDS decision-support systems.

This timely issue focuses on sediment transport through swales, water sensitive urban design and green infrastructure tools, hydrodynamic performance of air-water flows in gullies, fecal coliform loads in urban watersheds, infiltration performance of pavements, bioretention challenges, climate change, and urbanization. Furthermore, the increased importance of ecosystem services offered by SuDS became particularly apparent.

In times of recession, this Special Issue on modern SuDS has shown that expert systems supporting drainage engineers and scientists undergo a revival. However, the retrofitting of sustainable water structures is predominantly undertaken ad hoc using engineering experience supported by minimal 
formal guidance [1]. There is a lack of practical decision support tools to be used in different professions for the rapid assessment of potential ecosystem services that could be created when retrofitting water structures such as SuDS.

Thus an innovative decision support tool based on the rapid estimation of novel ecosystem service variables at low cost and acceptable uncertainty has been presented in this Special Issue [2]. This novel and timely tool proposes the retrofitting of those $\mathrm{SuDS}$ techniques that obtained the highest ecosystem services score for a specific urban site after assessment by a representative of one of the recognized professions.

The estimation of variables was undertaken with high confidence and manageable error at low cost [2]. In contrast to common public opinion, statistically significant differences were found between social scientists and the general public for the estimation of land costs using the non-parametric Mann-Whitney U-test. It was also surprising to find no significant differences in the estimation of habitat for species by civil engineers and ecologists. The new methodology may lead to an improvement of the existing urban landscape by promoting ecosystem services.

This collection of timely research articles and reviews has considerably informed a new textbook on wetland systems for water pollution control [3], covering the following discussed topics: SuDS, sustainable flood retention basins, integrated constructed wetlands, ponds, contaminated sediment, storm water quality, and decision support systems (Figure 1). Multi-disciplinary approaches, such as the ecosystem services concept to solve engineering science challenges with a holistic angle, have also been considered [2].

\section{Sustainability Civil Engineering \\ Decision Support Systems}

Air

Aquaculture

Watercourse Remediation

Developing Countries
Dam Risk Failure Measurement

Retention Basins

Sustainable Flood Retention Basins

Water Resources

Algal Control

Detention Tanks

\section{Water}

Eutrophic Rivers

Ponds

Silt Traps

\section{Sustainable Drainage Systems}

Sediment

Storm water

Ditches

Permeable Pavements

Wetland Systems Integrated Constructed Wetlands

\section{Contaminated Sediment Soil}

Dinking Water
Treatment Wetlands Membranes Biosensors Capillary Suction Time

Activated Carbon

Materials

Figure 1. Overview of special issue research areas and their corresponding relative importance (the larger and bolder the font the more important), and linkages (the closer located to each other the more related) between them. 
Latest research findings (beyond this special issue on SuDS) on infiltration, ponds, wetlands, climate change, decision-support systems and ecosystem services have been revisited and critically reviewed in the textbook [3], providing further detailed information, as well as a broader context to the readers of Water. Critical assessments deal comprehensively not only with the design, operation, maintenance, and water quality monitoring of traditional and novel wetland systems and SuDS, but also with the analysis of asset performance and modeling of treatment processes and performances of existing infrastructure predominantly in developed but also developing countries, and the sustainability and economic issues involved.

\section{References}

1. Woods-Ballard, B.; Kellagher, R.; Martin, P.; Jefferies, C.; Bray, R.; Shaffer, P. The SuDS Manual; Reprint to Incorporate Errata Since its Publication in 2007; Construction Industry Research and Information Association: London, UK, 2011.

2. Scholz, M.; Uzomah, V.C.; Almuktar, A.A.A.N.; Radet-Taligot, J. Selecting sustainable drainage structures based on ecosystem service variables estimated by different stakeholder groups. Water 2015, 5, 1741-1759.

3. Scholz, M. Wetlands for Water Pollution Control, 2nd ed.; Elsevier: Amsterdam, The Netherlands, 2015, in press.

(C) 2015 by the authors; licensee MDPI, Basel, Switzerland. This article is an open access article distributed under the terms and conditions of the Creative Commons Attribution license (http://creativecommons.org/licenses/by/4.0/). 